\title{
Preferences of ICT Tools by the Upazila Agriculture Officers (UAOs) for the Information Exchange in Bangladesh
}

\author{
Khondokar Humayun Kabir*, Debashis Roy \\ Department of Agricultural Extension Education, Bangladesh Agricultural University, Mymensingh, Bangladesh \\ Email address: \\ Kabirag09@bau.edu.bd (K. H. Kabir),droyagext@bau.edu.bd (D. Roy) \\ To cite this article: \\ Khondokar Humayun Kabir, Debashis Roy. Preferences of ICT Tools by the Upazila Agriculture Officers (UAOs) for the Information \\ Exchange in Bangladesh. Agriculture, Forestry and Fisheries. Vol. 4, No. 2, 2015, pp. 59-65. doi: 10.11648/j.aff.20150402.16
}

\begin{abstract}
The purpose of the study was to investigate the preferences of ICT tools by the Upazila Agricultural Officers, Bangladesh for the exchange of information. Data were collected using distributed questionnaires among the respondents. The findings showed that majority of the respondents $(93.8 \%)$ had highly favorable attitude towards ICTs while $6.3 \%$ percent had moderately favorable attitude and there was no respondent had slightly favorable attitude towards ICTs. It also found that the highly preferred ICT tool by the UAOs is cell phone (1.76) and the second highly preferred tool is tab with the mean value 1.74, and on the other hand, internet (1.31) is the least preferred tools by the respondents. Correlation showed that age, job duration, personality characteristics, ambition and access to ICT tools showed significant relationship with the preferences of ICT tools by the UAOs. Challenges in using ICTs revealed that load shedding problem (2.21), lack of training facilities (2.19) and indifferences of farmers to get information through ICT (2.19) are the major challenges faced by the Upazila Agriculture Officers. Thus, it can be recommended that more ICT tools should be made available to the respondents with properly addressing the challenges so that they will be able to choose from various alternatives and also be able to gather and disseminate useful information to the farmers.
\end{abstract}

Keywords: ICT Tools, Preference, Upazila Agriculture Officer and Information Exchange

\section{Introduction}

\subsection{Background}

Agricultural extension service delivery all over the world has been concerned with communicating research findings and improved agricultural practices to farmers ([1]. The efficiency with which these information and practices are conveyed to farmers to a large extent would determine the level of agricultural productivity. The delivered information and practices may be of various types. The relevant information during the before- planting period may be crop management or scheduling of crop activities [12, 23] improved seedlings [9] input price and availability [18, 23] and soil fertility ([2]. During the growing season, other types of useful information may play crucial roles in improving the amount and the quality of products. This may include weather information [18, 23], fertilizer supply [2], fertilizer use in terms of amount and timing [12], pest surveillance and management $[2,12,18,23]$ type and dosage of pesticides [12], weed control ([2] and disease management [12, 23]. Following the harvest, information about market opportunities [8], financial planning and market prices may be required [8, 9 and 23]. Extension organizations have been concerned with what should be the appropriate means and approaches in getting the right agricultural information to the end-users (farmers). In recent times however, there has been revolution with regards to Information and Communication Technology (ICT) in agriculture and particularly in extension service delivery of Bangladesh. This revolution is an intervention with the potential to ensure that knowledge and information on important agricultural technologies, methods and practices are put into right use by farmers [3].

Information and Communication Technologies (ICTs) are all technologies used for the widespread transfer and sharing of information. ICT tools include computer, internet, phone, television, radio, and other offline and online communication devices [6]. ICTs are rapidly consolidating global communication networks and international trade with applications for people in developing countries [14]. ICTs in agriculture promote and distribute new and existing farming information and knowledge which is communicated within the agricultural sector since information is essential for facilitating agricultural and rural development as well as 
bringing about social and economic changes [22]. There is growing recognition that farmers and members of rural communities have needs for information and appropriate learning methods that are not being met [4, 13]. The agriculture sector could leverage the Information and Communication Technologies (ICT) to disseminate the right information at the right time and right place. The cost factor in traditional information dissemination and the difficulties in reaching the target audiences have necessitated the introduction of ICT in agriculture [7].

\subsection{Problem Statement}

Agriculture is the important sector and key contributors to the national GDP of Bangladesh. Around $20.60 \%$ of the total GDP of the country comes from the agricultural sector [11].
Although Bangladesh is relatively late in entrant to eAgriculture, the foundation for leveraging ICTs for agricultural capacity building and marketing existed for long time. It is only recently that the [15] Government of Bangladesh (GoB) through the Department of Agricultural Extension and the Department of Agricultural Marketing has started harnessing ICTs for effectively to deliver information and services to the farmers [19]. In Bangladesh, the Department of Agricultural Extension (DAE), the principle extension agency of the Government, remains the largest public agency with the representative at national, divisional, district, upazila and village levels [5]. DAE and other nongovernment organizations operating in rural areas of the country are providing agricultural extension services to farmers [10].

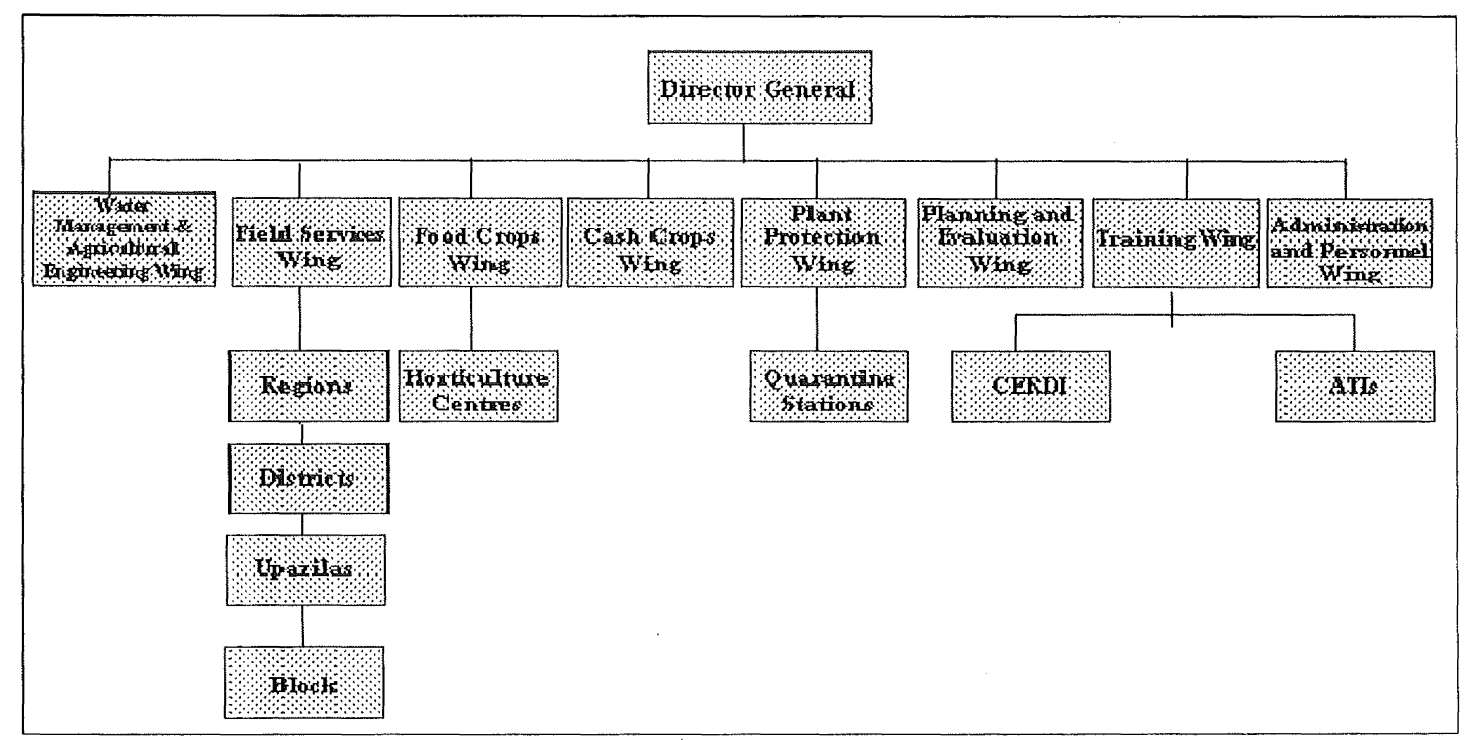

Figure 1. Organizational structure of Department of Agricultural Extension, Bangladesh.

Source: DAE, Bangladesh

Upazila Agriculture Officers (UAOs) under field service wing, DAE are mainly responsible for dissemination of necessary agricultural information to the farmers in the field level. They usually identify farmers' need and provide necessary solutions to them through different traditional extension teaching methods and to some extent through modern information and communication technologies. But, presently, the extension personnel are exploring to use different ICT tools in case of agricultural information/technology dissemination to the farmers. Because, the ratio of the farm families to the extension agent is $1000: 1$, this is really very little [16]. On the other hand, although the appointed Village Local Workers (VLWs) disseminate the information, they hardly accept any accountability. The cost factor in face-to-face information dissemination at the right time, and the difficulties in reaching the target audiences, has also created the urgency to introduce ICT [11]. Thus, the present study is an attempt to investigate the preferences of different ICT tools by the Upazila Agricultural Officers.

\subsection{Specific Objectives of the Study}

The following specific objectives have been taken into consideration to complete the study. These are:

a) To determine the attitude of the UAOs towards ICTs;

b) To investigate the preferences of ICT tools by the UAOs; and

c) To explore the challenges faced by the UAOs in using ICT tools.

\section{Methodology}

The study was carried out in Bangladesh Agricultural University, Mymensingh, Bangladesh. The participants in the workshop on 'Biotechnology with special emphasis on Bt. Brinjal' organized by Department of Agricultural Extension Education, BAU were the respondents of this study. A sample of about 80 was selected randomly from the total participants (208), covering $38.46 \%$ of the participants of workshop and representing the all agro-ecological zones of Bangladesh. 
Data were collected through distributed questionnaire method and a structured questionnaire was designed based on related literature and objectives of the study. Validity of the instrument was ensured through a panel of experts in the Department of Agricultural Extension Education and extension professionals from the Department of Agricultural Extension (DAE), Bangladesh.

Measurement of personality: Personality of the respondents was measured by using a four-point rating scale. Some personality characteristics viz. knowledgeable, ability to initiate, flexible, fearless, industrious, sincere and persevere were included in the scale. Weights of responses were: 3 for highly, 2 for moderately, 1 for low and 0 for not at all. The personality of a respondent was, therefore, determined by adding the total responses against 7 characteristics. The personality score could vary from 0 to 21,0 indicating 'no personality' and 21 indicating 'high personality'.

Collected data were tabulated, coded and assigned scores, wherever required in order to make them meaningful. Coded/scored data were analyzed using Statistical Package for Social Sciences (SPSS). Descriptive statistics such as frequency distribution, percentage analysis, mean, standard deviation, rank order (whenever necessary) and Pearson product-moment correlation analysis was used to test the strength of association among variables.

\section{Findings and Discussion}

\subsection{Socio-Economic Profile}

Socio-economic characteristics of the Upazila Agriculture Officers were analyzed and presented in Table 1.

From Table 1, the mean age of the UAOs was 44.6 years with majority of them (71.3\%) had Master of Science degree. The average job duration of the UAOs 19.27 years and a mean of 10.40 years as using ICT tools as first experience.

Table 1. Salient Features of the Selected Characteristics of the Upazila Agriculture Officers.

\begin{tabular}{|c|c|c|}
\hline \multirow{2}{*}{ Socio-economic variables } & \multicolumn{2}{|l|}{ Respondents $(\mathrm{n}=\mathbf{8 0})$} \\
\hline & Mean (Std. deviation) & Percentage \\
\hline \multicolumn{3}{|l|}{ Personal data } \\
\hline Age (years) & $40.65(7.10)$ & - \\
\hline Young (up to 30 ) & - & 6.2 \\
\hline Middle Aged (31-50) & - & 90.0 \\
\hline Old Aged (above 50) & - & 3.8 \\
\hline Level of Education & - & - \\
\hline B. Sc. Ag. (Hons.) & - & 22.5 \\
\hline Master of Science (MS) & - & 71.3 \\
\hline Doctor of Philosophy (PhD) & - & 6.2 \\
\hline Total Duration of Job (years) & $19.27(7.92)$ & - \\
\hline First Experience of ICT tools (years) & $10.40(4.43)$ & - \\
\hline \multicolumn{3}{|l|}{ Level of Job Satisfaction } \\
\hline Low & - & 12.5 \\
\hline Medium & - & 67.5 \\
\hline High & - & 20.0 \\
\hline Personal Character & $16.41(2.29)$ & - \\
\hline Low Personality ( up to 7) & - & 0 \\
\hline Medium Personality (8-14) & - & 27.5 \\
\hline High Personality (above 14) & - & 72.5 \\
\hline Ambition & $8.55(1.80)$ & \\
\hline Low (up to 3) & - & 2.5 \\
\hline Medium (4-6) & - & 11.2 \\
\hline High (above 6) & - & 86.3 \\
\hline Do you think ICT can change our technology dissemination system? & - & - \\
\hline $0=\mathrm{No}$ & - & 7.5 \\
\hline $1=$ Yes & - & 92.5 \\
\hline Extension Contact (days) & $19.54(7.93)$ & - \\
\hline Possible Range (0-51) & $19.04(1.95)$ & - \\
\hline Low Contact (up to 17) & - & 40.0 \\
\hline Medium Contact (18-34) & - & 58.9 \\
\hline High Contact (above 34) & - & 1.1 \\
\hline \multicolumn{3}{|l|}{ Training Received (In country) } \\
\hline $0=\mathrm{No}$ & - & 46.3 \\
\hline $1=$ Yes & - & 53.8 \\
\hline \multicolumn{3}{|l|}{ Foreign Training Exposure } \\
\hline $0=\mathrm{No}$ & - & 70.0 \\
\hline $1=$ Yes & - & 30.0 \\
\hline
\end{tabular}

Source: Field survey, 2014

More than two-third of the UAOs (67.5\%) had medium job satisfaction and majority of them (72.5\%) possessed high personality. More than four-fifth of the UAOs (86.3\%) was highly ambitious, while, majority of them (92.5\%) thought 
that ICTs can change technology dissemination system. The mean extension contact of the UAOs was 19.54 and about half of them $(53.8 \%)$ had in country training exposure, while, majority of them $(70.0 \%)$ had no foreign training exposure.

\subsection{Access to ICT tools}

This section examines the level of access and nature of access to selected ICT tools by the respondents. The findings have been shown in Table 2 .

Table 2. Access to ICT tools.

\begin{tabular}{|c|c|c|c|c|c|c|}
\hline \multirow{2}{*}{ ICT tools } & \multicolumn{4}{|l|}{ Level of Access } & \multirow{2}{*}{ Mean } & \multirow{2}{*}{ Rank Order } \\
\hline & Adequate access & Moderate access & Limited access & No Access & & \\
\hline Cell Phone & 63 & 11 & 6 & 0 & 2.71 & 1 \\
\hline Internet & 33 & 36 & 9 & 2 & 2.25 & 2.5 \\
\hline Digital Camera & 35 & 23 & 21 & 1 & 2.25 & 2.5 \\
\hline Print Media & 29 & 28 & 18 & 5 & 2.01 & 4 \\
\hline Multimedia Projector & 29 & 21 & 27 & 3 & 1.95 & 5 \\
\hline Video Chatting & 7 & 18 & 37 & 18 & 1.18 & 7 \\
\hline
\end{tabular}

The results of the analysis on the access to ICT tools indicate that majority of the respondents (2.71) had the access to cell phone for transferring agricultural information. Williams and Agbo [24] found similar findings. The second majority of the respondents had access to internet (2.25) and digital camera (2.25) where some respondents had access to print media (2.01), multimedia projector (1.95) and video chatting (1.18). The findings indicate that only few of the respondents $(0.80)$ had access to tab and hence it got the lowermost position in the rank order.

\subsection{Use of ICT Tools}

Use of common ICT tools was evaluated by inquiring the availability or accessibility to the cell phone, tab, internet, video chatting, multimedia projector, digital camera and print media. The findings have been presented in Table 3 .

As shown in Table 3, more than four-fifth of the UAOs (88.8\%) uses cell phone while the access to tab was $41.3 \%$. This is in line with research by Seepersad [21] who reported that cell phones are fairly common among extension employees in Trinidad and Tobago. Samansiri and Wanigasundera [20] found similar results. Majority of the respondents $(87.5 \%)$ uses internet to transfer necessary information while $52.5 \%$ and $75.0 \%$ of the respondents uses video chatting and multimedia projector for transferring agricultural information, respectively.

Table 3. Use of ICT tools by Upazila Agriculture Officers.

\begin{tabular}{lllll}
\hline \multirow{2}{*}{ ICT tools } & Yes & \multicolumn{3}{l}{ No } \\
\cline { 2 - 5 } & Frequency & Percentage & Frequency & Percentage \\
\hline Cell Phone & 71 & 88.8 & 9 & 11.3 \\
Tab & 33 & 41.3 & 47 & 58.8 \\
Internet & 70 & 87.5 & 10 & 12.5 \\
Video Chatting & 42 & 52.5 & 38 & 47.5 \\
Multimedia & 60 & 75.0 & 20 & 25.0 \\
Projector & & 87.5 & 10 & 12.5 \\
Digital Camera & 70 & 76.3 & 19 & 23.8 \\
Print Media & 61 & & & \\
\hline
\end{tabular}

More than four-fifth of the respondents $(87.5 \%)$ uses digital camera while $76.3 \%$ of them uses print media to disseminate information to the farmers.

\subsection{Purpose of Using ICT Tools}

The purpose of using ICT tools formulated five major purposes such as retrieve information, video chatting, downloading videos, communication and collection of different training materials. The findings have been presented in Table 4.

Table 4. Purpose of using ICT tools.

\begin{tabular}{|c|c|c|c|c|}
\hline \multirow{2}{*}{ Purposes } & \multicolumn{2}{|l|}{ Yes } & \multicolumn{2}{|l|}{ No } \\
\hline & Frequency & Percentage & Frequency & Percentage \\
\hline Retrieve Information & 73 & 91.3 & 7 & 8.8 \\
\hline For Video Chatting & 51 & 63.8 & 29 & 36.3 \\
\hline For Downloading different Videos & 60 & 75.0 & 20 & 25.0 \\
\hline For Communication & 68 & 85.0 & 12 & 15.0 \\
\hline For Collection of different Training Materials & 71 & 88.8 & 9 & 11.3 \\
\hline
\end{tabular}

Table 4 shows that majority of the respondents use ICT to retrieve different information while $63.80 \%$ of them use for video chatting. Three-fourth of the respondents use ICT for downloading different videos and more than four-fifth of them communicate through ICTs, where $88.8 \%$ of the respondents use ICT for collecting different training materials.

\subsection{Attitude towards ICTs}

The possible attitude score of the respondents towards ICTs could range from $8-24,8$ indicating highly unfavorable attitude and 24 indicating highly favorable attitude. The computed attitude scores of the respondents ranged from 1322 where, mean being 18.11 with a standard deviation of 1.98 . 
Table 5. Classification of the respondents according to their attitude towards ICTs.

\begin{tabular}{|c|c|c|c|c|c|c|}
\hline Possible Score & Observed Score & Categories of Farmers & Number & Percentage & Mean & SD \\
\hline \multirow{4}{*}{$8-24$} & \multirow{4}{*}{$13-22$} & Slightly favorable (up to 7) & - & - & \multirow{4}{*}{18.11} & \multirow{4}{*}{1.98} \\
\hline & & Moderately favorable (8-14) & 5 & 6.3 & & \\
\hline & & Highly favorable (above 14) & 75 & 93.8 & & \\
\hline & & Total & 80 & 100 & & \\
\hline
\end{tabular}

Data indicated that almost all of the respondents (93.8\%) had highly favorable attitude towards ICTs while $6.3 \%$ percent had moderately favorable attitude and there was no respondent had slightly favorable attitude towards ICTs. The finding indicates that the respondents were enthusiastic to adopt different ICT tools to disseminate required agricultural information to the farmers.

\subsection{Preferences of different ICT Tools}

To understand the preferences of ICT tools by the respondents a rank order of the commonly used ICT tools was made. The rank order is based on the mean value of each ICT tools and the mean value of individual tool ranges from 1.31 to 1.76 .

Table 6. Preferences of different ICT tools.

\begin{tabular}{|c|c|c|c|c|c|}
\hline \multirow{2}{*}{ ICT tools } & \multicolumn{5}{|c|}{ Degree of Preference } \\
\hline & Highly prefer & Moderately Prefer & Not at all & Mean & Rank Order \\
\hline Cell Phone & 63 & 15 & 2 & 1.76 & 1 \\
\hline Tab & 62 & 15 & 3 & 1.74 & 2 \\
\hline Video Chatting & 60 & 17 & 3 & 1.71 & 3.5 \\
\hline Multimedia Projector & 58 & 21 & 1 & 1.71 & 3.5 \\
\hline Digital Camera & 57 & 18 & 5 & 1.65 & 5 \\
\hline Print Media & 50 & 24 & 6 & 1.55 & 6 \\
\hline
\end{tabular}

Table 6 reveals that the highly preferred ICT tool by the UAOs is cell phone (1.76) and thus stood first in the rank order. Mabe and Oladele [14] stated that prominent information communication technologies among extension officers were mobile phones. The finding is also in line with research by Seepersad [21]. The second highly preferred tool is tab with the mean value 1.74 , and video chatting (1.71) and multimedia projector (1.71) are equally preferred by the respondents. It also indicates that internet (1.31) is the least preferred ICT tool by the respondents. This finding may be due to there was insufficiency of internet facilities and may also be the difficulties in operating internet.

\subsection{Relationship between Independent Variables and Focus Variable}

This subsection is carried out an assessment of the relationship between the socioeconomic characteristics of the respondents and their preferences of ICT tools. The results have been shown in table 7 .

Table 7. Correlation between the selected characteristics of the UAOs and their preferences on using ICT tools.

\begin{tabular}{ll}
\hline Independent Variables & Correlation of Coefficients (r) \\
\hline Age & $-0.251^{*}$ \\
Duration of first ICT tools & 0.200 \\
Total duration of training & 0.151 \\
Total duration of job & $-0.301^{* *}$ \\
Personal characteristics & $0.249^{*}$ \\
Ambition & $0.295^{* *}$ \\
Access to ICT tools & $0.638^{* *}$ \\
\hline
\end{tabular}

*Significant at the 0.05 level of probability (2-tailed)

** Significant at the 0.01 level of probability (2-tailed)
Table 7 reveals that out on seven characteristics five viz. age, duration of job, personal character, ambition and access to ICT tools found to be related with the focus variables. Personal characters, ambition and access to ICT tools showed positive relationship with the focus variable. It is found the personality characteristics shows significant and positive relationship with the focus variable and it can be implied that the higher personality, more preferences to ICT tools. The person who posses high personality characteristics usually willing to make them updated with the modern technologies and are likely to accept any change rapidly. It is also found that ambition of the respondents showed significant and positive relationship with the focus variable. Thus, it can be implied that the higher ambition of the officers, higher preferences to ICT tools. The result may be due to the ambitious people are more positive to any kind of change and are likely to make their betterment by using modern facilities. Access to ICT tools showed significant and positive relation with the preferences of ICT tools. It can be implied that more access to ICT tools, higher the preferences of ICT tools. Access to ICT tools provide the range of different tools where the respondents have facilities to use different tools and hence the result seems to be like this. On the other hand, age and job duration showed negative relationship i. e. older and more job experienced officers are likely resistant to use ICT tools for the exchange of agricultural information rather they use traditional methods to do so. Older people are likely to have put in more years of work experience and be more resistant to change and innovations [17]. And hence, age and job duration showed significant and negative relationship with the focus variable. 


\subsection{Challenges Faced in Using Different ICT Tools}

This section examines the challenges to ICT usage among the respondents. The challenges in using ICT tools among the respondents are as presented in Table 8.

Table 8. Challenges faced in using different ICT tools.

\begin{tabular}{|c|c|c|c|c|c|c|}
\hline \multirow{2}{*}{ Challenges } & \multicolumn{6}{|c|}{ Extent of Challenges } \\
\hline & High & Medium & Low & Not at all & Mean & Rank Order \\
\hline Load shedding problem & 32 & 37 & 7 & 4 & 2.21 & 1 \\
\hline Lack of training facilities & 35 & 30 & 10 & 5 & 2.19 & 2.5 \\
\hline Indifferences of farmers to get information through ICT & 33 & 34 & 8 & 5 & 2.19 & 2.5 \\
\hline The price of different ICT tools have increased sharply & 16 & 52 & 6 & 6 & 1.98 & 4 \\
\hline Most of the ICT tools are sophisticated to use & 10 & 40 & 24 & 6 & 1.68 & 5 \\
\hline Gender Issues & 8 & 38 & 18 & 16 & 1.48 & 6 \\
\hline
\end{tabular}

Table 8 reveals that load shedding problem (2.21), lack of training facilities (2.19) and indifferences of farmers to get information through ICT (2.19) are the major challenges faced by the Upazila Agriculture Officers. Omotesho [17] found that load shedding is the second major challenge to extension agents in Nigeria. The increased prices of the ICT tools (1.98) and sophistication of using ICT (1.68) are the challenges faced by the respondents in using ICT tools. Furthermore, gender issue (1.48) is another challenge but it bears no significance and hence, got the lowest position in the rank order.

\section{Conclusions}

For easy, fast and cost effective means it is necessary to incorporate ICT tools in extension services for the exchange of useful information with the farmers. As the findings demonstrate favorable attitude towards ICT, it would be very much effective to disseminate useful agricultural information through different ICT tools and the extension personnel as well as the farmers could harvest maximum benefits out of it. The findings also indicate that cell phone and tab are the most preferred tools and thus, availability of these tools should be ensured. On the other hand, internet facilities should be available so that the respective stakeholders could make its better utilization in agricultural development activities. Load shedding problem, lack of training facilities, indifferences of farmers to get information through ICT are the major challenges faced in using ICT tools. Necessary efforts to overcome these challenges would ensure increased use of ICTs for agricultural activities. So, it can be mentioned that the authority could take necessary steps to provide infrastructural facilities such as constant electricity, ensure periodic training for both farmers and extension agents on the necessity and operation of ICTs, subsidize ICTs facilities and make available all networks in collaboration with the network providers.

\section{Acknowledgements}

The authors convey deepest thanks to Upazila Agriculture Officers (UAOs) for their cooperation during data collection. Moreover, authors convey their gratefulness to the Department of Agricultural Extension Education, Bangladesh Agricultural University, Mymensingh for arranging such workshop from where authors could collect data easily.

\section{References}

[1] Agbamu, J. U. (2007). Essentials of Agricultural Communication in Nigeria. Malthouse Press Limited Lagos. pp. 20-24, 91-93.

[2] Ekoja, I.I. (2004). Sensitising users for increased information use: the case of Nigerian farmers. African Journal of Library. Archives and Information Science, 14(2):193-204.

[3] Ezeh Ann N, (2013). Extension Agents access and utilization of Information and Communication Technology (ICT) in Extension Service Delivery in South East Nigeria. Journal of Agricultural Extension and Rural Development, 5(11):266276.

[4] Greenidge, C. B. (2003). ICTs and the rural sector in ACP State: Mirage or Marriage? Address delivered at the CTA's ICT observatory U.S.A.

[5] Haque, J. T. (n.d.). Agrarian Transition and Livelihoods of the Rural Poor: Agriculture Extension Services. Unnayan Onneshan, Bangladesh.

[6] Hasan, M. R. \& Shariff, A.R.M. (2007). Study on the Telecenter Movement in Bangladesh: Obstacles and Opportunities; Rural ICT Development Conference, University Utara Malaysia, Kedah, Malaysia (November).

[7] Hasan, R., Islam, S., Rahman, M. S. \& Jewel, K. N. A. (2009). Farmers Access to Information for Agricultural Development in Bangladesh. Bangladesh Research Publication Journal, 2(1): $\quad 319-33$ 1. $\quad$ Retrieve form http://www.bdresearchpublications.com/admin/journal/upload/ 08043/08043.pdf

[8] International Institute for Communication and Development [IICD]. (2006). ICTs for agricultural livelihoods: Impact and lessons learned from IICD supported activities. The Hague: The Netherlands.

[9] Irivwieri, J.W. (2007). Information needs of illiterate female farmers in Ethiope East local government area of Delta State. Library Hi Tech News, 9(10): 38-42.

[10] Karim, Z., Bakar, M. A. and Islam, M. N. (2009). Study of the Implementation Status and Effectiveness of New Agricultural Extension Policy for Technology Adoption. Center for Agriresearch and Sustainable Environment and Entrepreneurship (CASEED). Final Report. 
[11] Kashem, M. A., Farouque, M. A. A., Ahmed, G. M. F. and Bilkis, S. E. (2010). The complementary roles of information and Communication technology in Bangladesh agriculture, Journal Science Foundation, 8(1\&2): 161-169.

[12] Krishna Reddy, P. \& Ankaiah, R. (2005). A framework of information technology-based agriculture information dissemination system to improve crop productivity. Current Science, 88(12): $1905-1913$.

[13] Lightfoot, C. (2003) Demand -driven extension: some challenges for policy makers and managers. ICTs Transforming Agricultural Extension? The 6th Consultative Expert Meeting of CTA's Observatory on ICTs, Wageningen, 23-25 September, 2003.

[14] Mabe L. K. \& Oladele O.I. (2012). Awareness level of use of Information Communication Technologies tools among Extension officers in the North- West Province, South Africa. Life Science Journal, 9(3): 440-444.

[15] Ministry of Agriculture. (1999). Agricultural Extension Manual, Department of Agricultural Extension, Bangladesh

[16] NAEP. (1996). New Agricultural extension Policy, Govt. of the People's Republic of Bangladesh, Ministry of Agriculture. p-8.

[17] Omotesho, K. F., Ogunlade, I. O. \& Lawal, M. (2012). Assessment of Access to Information and Communication Technology among Agricultural Extension Officers in Kwara State, Nigeria. Asian Journal of Agriculture and Rural Development, 2(2): 220-225.
[18] Rao, S. S. (2004). Role of ICTs in India's rural community information systems. Info, 6(4): $261-269$.

[19] Rubaiya, A. (2010). Bangladesh. In R. Saravanan (ed). ICTs for Agricultural Extension: Global Experiments, Innovations and Experiences (pp. 1-43). New India Publishing Agency, Pitam pura, New Delhi.

[20] Samansiri, B. A. D. and Wanigasundera, W. A. D. P. (2014). Use of Information and Communication Technology (ICT) by Extension Officers of the Tea Small Holdings Development Authority of Sri Lanka. Tropical Agricultural Research, 25 (4): $360-375$.

[21] Seepersad, J. (2003). Case study in ICTs in Agricultural Extension in Trinidad and Tobago. In CTA ICTS Transforming Agricultural Extension? The $6^{\text {th }}$ Consultative Expert Meeting of CTA's Observatory on ICTs, Wageningen, 23- 25 September, 2003.

[22] Swanson, B, E. \& Rajalahti, R. (2010). Strengthening Agricultural Extension and Advisory Systems: Procedures for Assessing, Transforming and Evaluating Extension Systems, The International Bank for Reconstruction and Development/The World Bank, Washington, pp. 98 - 127.

[23] Tiwari, S. P. (2008). Information and communication technology initiatives for knowledge sharing in agriculture. Indian Journal of Agricultural Sciences, 78(9): 737 -747.

[24] Williams, E. E. \& Agbo, I.S. (2013). Evaluation of the Use of ICT in Agricultural Technology Delivery to Farmers in Ebonyi State, Nigeria. Journal of Information Engineering and Applications, 3 (10):18-26. 